\title{
Sterols in Rumen Oligotrich Protozoa
}

\author{
Tsuneo Hino and Masao Kametaka \\ Department of Agricultural Chemistry, Faculty of Agriculture, \\ University of Tokyo, Tokyo 113 \\ (Received June 24, 1975)
}

\begin{abstract}
Steroids in rumen oligotrich protosoa were analysed principally by thin-layer chromatography, gas-liquid chromatography and mass spectrometry. As the major ster-

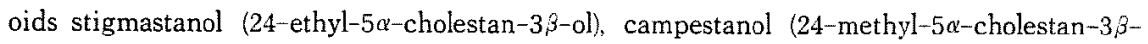
ol) and cholestanol $(5 \alpha-$ cholestan-3 $\beta$-ol) were identified, and the presence of other unidentified sterols as the minor constituents was shown. The former two stanols appear to be derived from feed sterols by hydrogenation, but metabolic origin of cholestanol is not clear enough. Total sterol content of these protozoa was usually $0.6-0.9 \%$ of dry matter and $6-7 \%$ of total lipid in weight. The sterol composition was stigmastanol $60-$ $-66 \%$, campestanol $13-15 \%$, cholestanol $11-17 \%$ and other sterols $7-9 \%$. A markedly high proportion of cholestanol was found in the protozoa collected from a goat fed an almost steroid-free diet. The short-term growth culture of protozoa in a steroid-free medium resulted in a marked decrease of the total sterol per dry matter. This dilution was caused by protozoal growth accompanied with slight decrease in the absolute amount of total sterols, in spite of the remarkable increase of cholestanol in the absolute quantity. The rise of cholestanol indicates that this stanol is either synthesized de novo or derived from other sterols. These results show that protozoa are uncapable of maintaining their total sterol level without exogenous steroids, even though they are able to synthesize cholestanol. This may explain, at least in part, the fact that rumen protozoa require exogenous sterols for their optimal growth.
\end{abstract}

We reported previously that sterols stimulated the growth of rumen protozoa (at least Entodinium sp.) both in vitro ${ }^{1)}$ and in vivo $0^{2)}$. Sterol requirement by other groups of ciliated protozoa, e.g., some species of Paramecium ${ }^{3-5)}$, Tetrahymena ${ }^{6-8)}$, Colpidium ${ }^{9,10)}$ and Stylonychia ${ }^{11}$, has been reported by several workers, but little is known of the function of sterols in protozoa. However, referring to the function of sterols suggested for other organisms, e.g., insects ${ }^{12)}$, Mycoplasma $^{13.14)}$ and fungi ${ }^{13,15}$, it seems probable that sterols fulfil some metabolic functions and/or serve as a structural component, especially as a membrane constituent.

As reported previously ${ }^{1}$, the response of entodinia varies with different sterols, but there is no knowledge concerning the behavior of sterols within protozoal cells; whether active sterols given to protozoa are present in unchanged form or converted to other biologically active forms remains unclear. Therefore, an attempt was made to analyse steroids in rumen protozoa and to investigate the metabolic relationships between intracellular steroids and exogenous ones.

As far as we are aware, little accurate information has been obtained on steroids of rumen protozoa; only one report on sterols of holotrich ciliates has been presented by $K_{d T Z} Z$ and KEENEY Jap. J. Zootech.Sci., 46, (12) : 693-705. 


\section{HiNo and KAMETAKA}

16), who tentatively identified cholestanol as a protozoal sterol and $\alpha$-spinasterol as a sterol originating from a diet. However, the identification made by them is not complete enough for characterization of the sterols, and furthermore it can be expected that other steroids may exist in rumen protozoa. With respect to steroids of oligotrich species no information has been available.

This paper reports the first part of our study in which major steroids in oligotrich protozoa from the rumen of goats were identified. In addition, to aid the elucidation for the origin of protozoal steroids, bacteria collected simultaneously from the rumen were also analysed.

In this paper, the following terms are used for steroids: Sterols; steroids with a hydroxy group at $\mathrm{C}-3$, stanols; saturated sterols, stenols; unsaturated sterols, cholestanol; $5 \alpha$-cholestan- $3 \beta$ -

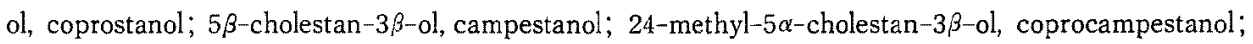
24 -methyl-5 $\beta$-cholestan- $3 \beta$-ol, stigmastanol; 24-ethyl $-5 \alpha$-cholestan-3 $\beta$-ol, coprostigmastanol; 24 -

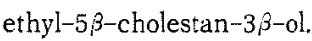

\section{Materials and Methods}

\section{Preparation of protozoa and bacteria for analysis}

Rumen-fistulated goats mentioned previously ${ }^{2}$ ) were used as a source of rumen protozoa and bacteria. The animals were fed twice daily $(10 \mathrm{a}, \mathrm{m}$. and $6 \mathrm{p} . \mathrm{m}$.) a ration containing alfalfa hay cubes, green grass and commercial formula feed for cows. Rumen contents were collected, unless otherwise stated, before morning feeding. The contents were strained through four layers of gauze, and the filtrate was then incubated at $39^{\circ} \mathrm{C}$ so that feed debris might float up. After $1 \mathrm{hr}$ the lower layer was withdrawn, and protozoa were collected by centrifugation at $200 \times \mathrm{g}$ for $5 \mathrm{~min}$. This process was repeated after the protozoa were incubated in a mineral salt solution ${ }^{17}$ ) for $1 \mathrm{hr}$. The protozoa thus obtained were further purified by washing repeatedly with $0.8 \% \mathrm{NaCl}$ solution until the supernatant was clear. These purified protozoa are hereafter referred to as mixed protozoa. The approximate composition of this preparation was usually $80 \%$ entodinia, $15 \%$ other oligotrichs and $5 \%$ holotrichs. In order to obtain oligotrich protozoa, mixed protozoa were incubated anaerobically in a mineral salt solution containing $0.6 \% \mathrm{D}$-mannose ${ }^{18)}$ for $10-12 \mathrm{hr}$. After washing several times the protozoa were used as an oligotrich sample, which included less than $0.5 \%$ holotrichs. To obtain entodinia, mixed protozoa were cultured for 8 days in Medium E under Condition $\mathrm{A}^{17}$, and then remaining entodinia were harvested.

A bacterial sample was prepared as follows: The supernatant of rumen fluid, after collection of protozoa by centrifugation as mentioned above, was centrifuged again for complete removal of remaining protozoa. The resultant supernatant was incubated for $2 \mathrm{hr}$, and after removal of floating debris bacteria were collected by centrifugation at $18,000 \mathrm{xg}$ for $20 \mathrm{~min}$. The bacteria were then purified by washing with $0.7 \% \mathrm{NaCl}$ solution. Microscopic examination showed that the bacterial preparation was apparently free from protozoa, although slight contamination of feed fragments was observed.

\section{Incubation conditions of protozoa and bacteria}

Protozoa and bacteria collected as above were incubated for $12 \mathrm{hr}$ at $39^{\circ} \mathrm{C}$ in a mineral salt solution under a flow of nitrogen gas. As a control the microorganisms killed by addition of 0.1 $\% \mathrm{HgCl}_{2}$ were simultaneously incubated. For short-term growth culture in the absence of steroids, oligotrich protozoa were incubated for 2 days in a chemically defined medium containing no steroids (already reported as the basal medium ${ }^{1}$ ), since the protozoa were found to keep growing as long as 2 days without any exogenous steroid. 


\section{Extraction of lipids and separation of sterols.}

Wet cells of protozoa and bacteria were extracted three times with 10 volumes each of chloroform-methanol (2:1) for $12 \mathrm{hr}$ at room temperature. The crude lipids were saponified by refluxing with $5 \% \mathrm{KOH}$ in $90 \%$ aqueous ethanol for $3 \mathrm{hr}^{1}$. The unsaponifiable fraction was subjected to thin-layer chromatography (TLC), and then to gas-liquid chromatography (GLC) to separate sterols as described below. Sterols having a $3-\beta$ hydroxy group were isolated by means of the tomatinide formation method as described previously ${ }^{19}$.

Sterols in feces were also analysed in the same way using wet feces collected from the same goats.

Conditions of TLC

Thin-layer plates were prepared with Silica Gel G (E. MERCK) in the customary way, and the following development conditions were employed.

'Condition A': As a developing solvent, a mixture of chloroform-methanol-acetic acid-water $(90: 8: 1: 1)$ was used. In this solvent system, $4^{5}$-stenols, e.g., cholesterol, stigmasterol, campesterol and $\beta$-sitosterol, stanols, e.g., cholestanol and coprostanol, and ergosterol show an identical migration rate.

'Condition B': For the purpose of separation between stenols and structurally corresponding stanols, the so-called "bromine system"20) was employed, i.e., $0.5 \%$ of bromine was added to the mobile phase. In this case the solvent system of benzene-ethyl acetate (4:1) was used.

'Condition C': Plates were developed with petroleumether-ether-acetic acid (80:20:1), and after the solvent was dried off at $50^{\circ} \mathrm{C}$ development was repeated once with the same solvent. The condition under which plates were developed once is referred to as Condition $\mathrm{C}^{\prime}$.

'Condition D': Plates were impregnated with $20 \% \mathrm{AgNO}_{3}$ for the separation of sterols according to unsaturation class ${ }^{20)}$. In. this case the developing solvent was chloroform-acetone $(9: 1)$.

'Condition E': Development was carrid out in the solvent system of ether-heptane $(55 ; 45)^{21}$. This system enables a clear separation between $5 \alpha-$ and $5 \beta$-stanols, although $5 \alpha$-stanols overlap with $\Delta^{5}$-stenols.

For detection of spots, chromatoplates were sprayed with $50 \% \mathrm{H}_{2} \mathrm{SO}_{4}$ and then heated at 110 ${ }^{\circ} \mathrm{C}$ for 5-10 min. This treatment facilitates the color development which is characteristic of steroids, depending on the nuclear structure. When Condition $\mathrm{D}$ was employed, spots were detected by spraying with $20 \%$ phosphomolybdic acid in ethanol and then heating as above.

\section{Conditions of GLC}

Gas chromatographic separation was carrid out using a Shimadzu instrument, Model GC-6A, equipped with a hydrogen-flame ionization detector. Glass columns of 1 or $2 \mathrm{~m}$ in length were used, packed with $2 \%$ OV-17 coated on Chromosorb W (80-100 mesh). Operation conditions are described in the legend of figures. Samples for GLC were prepared by elution from Silica Gel after TLC separation. Sterols were analysed both as the free form and as the trimethylsilyl (TMS) ether. For quantitation the peak area of a sample was compared with that of $\beta$-sitosterol or cholesterol.

\section{Conditions of mass spectrometry}

Combined GLC-mass spectrometry (MS) was effected with a Hitachi RMU-6L mass spectrometer. Mass spectra were measured under the ionization voltage of $70 \mathrm{eV}$.

Standard sterols

Cholesterol, cholestanol, stigmasterol, ergosterol and estradiol were purchased from Tokyo Chemical Industry Co. Ltd. (Tokyo), and purified by repeated recrystallization from ethanol and 
TLC separation under Condition A, C and E. Coprostanol, campesterol, and $\beta$-sitosterol were supplied by Applied Science Laboratories Inc. (U.S. A.).

\section{Results}

(1) Analysis by TLC

As a preliminary experiment steroids in mixed protozoa were examined. On TLC under Condition A the unsaponifiable fraction gave two clear spots showing steroidal nature (Fig. 1-a); one (Spot $I$ ) had the same $R_{f}$ value as that of standard cholesterol $\left(R_{t}, 0.86\right)$ and the other (Spot II) $R_{f}$ 0.79. Spot I colored pink-purple and Spot II blue-violet, probably suggesting that the structure of the steroid nucleus is different each other, although both are evidently unsaturated.

When an oligotrich sample was chromatographed (Fig. 1-a), Spot II similarly colored blueviolet but Spot I was light brown immediately after the detection treatment. However, after the plate was subsequently left at room temperature for about half an hour this spot gradually grew purple, indicating a nature characteristic of stanols. That Spot I of oligotrichs was made up of stanols was confirmed by TLC separation under Condition B (Fig. 1-b) and also by esterification (see below, Fig. 2-b). An entodinial sample showed almost the same result as that obtained with the oligotrich sample.

It was shown by TLC under Condition B that stanols, in addition to stenols, were present in mixed protozoa (Fig. 1-b). In the case of the mixed protozoa incubated for $12 \mathrm{hr}$ without D-mannose, a spot for stanols was clearly seen but stenols were not present to any detectable degree

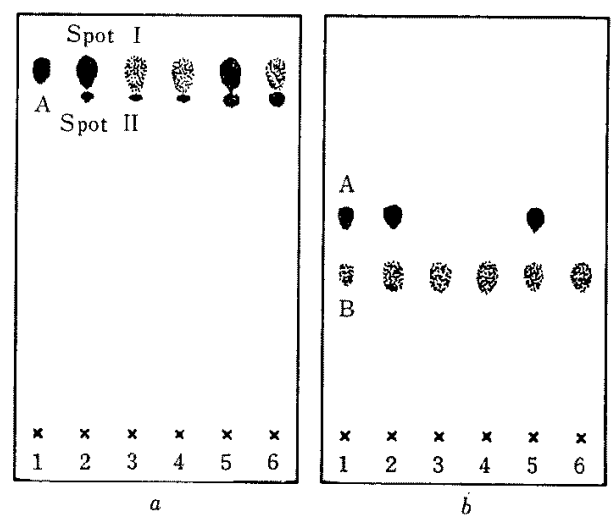

Fig. 1. Thin-layer chromatograms of sterols in rumen protozoa and bacteria.

(a) Unsaponifiable fractions of the samples shown below were subjected to TLC under Condition A.

(b) Spot I fractions obtained by elution of the gel after TLC separation under Condition A were chromatographed under Condition B.

Materials: 1) Standard (A; cholesterol, B; cholestanol), 2) Mixed protozoa, 3) Mixed protozoa incubated for $12 \mathrm{hr}$ without D-mannose, 4) Oligatrich protozoa, 5) Bacteria, and 6) Bacteria incubated for $12 \mathrm{hr}$.

Only spots indicative of sterols are shown. Black portions indicate the spots which were colored rapidly by the detection treatment, and dotted portions indicate the spots which were slower in color development. (For details see text.) 


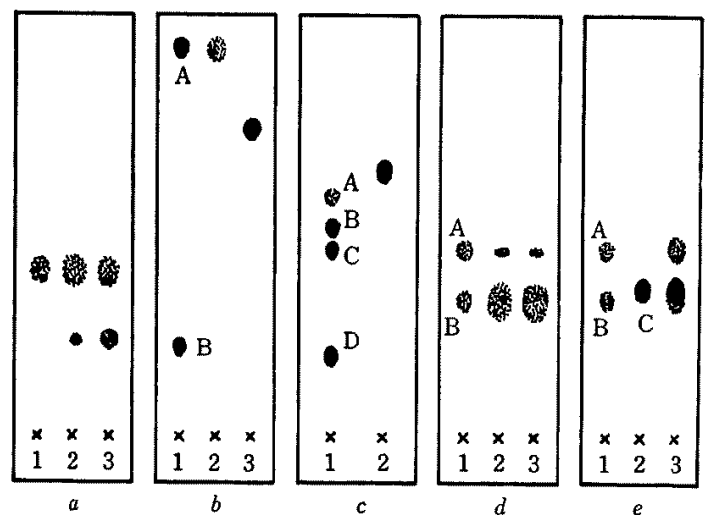

Fig. 2. Thin-layer chromatograms of stanols and Compound $\mathrm{X}$ in rumen protozoa and bacteria.

(a) Unsaponifiable fractions of oligotrich protozoa (2) and bacteria (3) were chromatographed under Condition C: Standard (1); cholestanol.

(b) Fractions of stanols (2) and Compound X (3) were acetylated, and then subjected to TLC under Condition $\mathrm{C}^{\prime}$ : Standard (1); cholesterol acetate (A) and cholesterol (B).

(c) Compound $\mathrm{X}$ (2) was chromatographed under Condition D: Standard (1); cholestanol (A), cholesterol (B), ergosterol (C) and estradiol (D).

(d) Stanol fractions of oligotrich protozoa (2) and bacteria (3) were chromatographed under Condition E: Standard (1); coprostanol (A) and cholestanol (B).

(e) Stanol fraction (containing also stenols) of the feces of a goat (3) was chromatographed under Condition E. Standard $(1,2)$; coprostanol (A), cholestanol (B) and cholesterol (C).

Expression of the figures is the same as that of Fig. 1.

(Fig. 1-b). The control experiment in which protozoa were killed showed no observable change by incubation. These results may suggest that stenols were ascribable to the feed materials taken up by protozoa, not ascribable to holotrichs, and that stenols were metabolized to stanols by protozoa or contaminating bacteria.

On analysis of the feed given to animals during these experiments, virtually no stanol was detected, although abundant stenols were found. Analysis of the bacteria from the rumen gave the results similar to those obtained with mixed protozoa, i.e., the bacterial sample prepared as described in Materials and Methods section contained both stenols and stanols, but after incubation for $12 \mathrm{hr}$ apparent absence of stenols was shown (Fig. 1-a,b). Therefore, it seems obvious that stenols are saturated by rumen bacteria. However, it is possible that protozoa also hydrogenate stenols, since the numbers of bacteria present in the protozoal sampels were perhaps extremely low, and moreover stenols disappeared even when mixed protozoa were incubated in the presence of antibiotics ${ }^{22)}$.

The substance responsible for Spot II (referred to as Compound $\mathrm{X}$ ), which was more separable by TLC under Condition $C$ than Condition A, was suggested to be more abundant in bacteria than protozoa by color intensity after the detection treatment (Fig. 2-a). Exact observations on color development showed that Compound $\mathrm{X}$ was colored purple first by heating only a few 


\section{HINO and KAMETAKA}

minutes and then turned blue-violet soon. This rapidity of color development was comparable to stenols having two double bonds in the nucleus, e.g., ergostercl; more rapid than $\Delta^{5}$-stenols such as cholesterol and $\beta$-sitosterol.

The stanols and Compound $\mathrm{X}$ collected separately by elution of each band after TLC under Condition $\mathrm{C}$ were esterified to form sterol acetates ${ }^{23}$. As shown in Fig. 2-b, on TLC under Condition $C^{\prime}$ the acetylated stanols migrated to the same $R_{f}$ value $(0.96)$ as that of cholesterol acetate, while acetylated Compound $X$ had the $R_{f}$ value 0.74 . Since the $R_{f}$ of original Compound $X$ was 0.19 , it seems evident that Compound $\mathrm{X}$ has at least one hydroxy group. The hydroxamic acid test assured the formation of an ester by the acetylation treatment. Compound $\mathrm{X}$ is not a steryl glucoside, because its behavior on TLC was not altered by acid hydrolysis ${ }^{19)}$ and moreover this compound was negative to the Molisch test. In the bromine system (Condition $\mathrm{B}$ ), Compound $\mathrm{X}$ was decomposed during development and only spots of the broken fragments appeared near the solvent front, just as observed on ergosterol. According to Copius-Peereboom and BeEkes ${ }^{20)}$, sterols having a system of conjugated double bonds and sterols devoid of the normal $4^{5}$-double bond, e.g., $\Delta^{7}$-and $\Delta^{8}$-stenols, are completely decomposed in the bromine system. These observations may suggest that Compound $\mathrm{X}$ is not a normal $d^{5}$-stenol but a sterol with two or more double bonds in its nucleus. TLC under Condition D failed to provide information on the number of double bonds in Compound X, possibly because of the greater effect of other factors, e.g., the presence of substitution groups and the structure of the side chain (Fig. 2-c).

By TLC separation of the stanol fractions of oligotrich protozoa and bacteria performed under Condition E, $5 \alpha$-stanols were found as the maijor constituent, with only a trace of $5 \beta$-stanols (Fig. $2-d)$. Similarly, whole rumen contents were shown to contain an extremely low level of $5 \beta$-stanols, compared with the amount of $5 \alpha$-stanols, while in the feces of the same animal comparatively abundant $5 \beta$-stanols were found (Fig. 2-e). This may suggest that rumen microorganisms are considerably different from intestinal ones in the transformation of sterols.

Precipitation by treatment with tomatine indicated that both the stanols and Compound $\mathrm{X}$ possess a hydroxy group at $\mathrm{C}-3$ with the $\beta$-configuration.

(2) Analysis by GLC

After TLC separation of an oligotrich sample under Condition A, stanols and Compound X were collected together by elution of their bands, and then the combined sterol fraction was analysed by GLC using $1 \mathrm{~m}$ columns. As shown in Fig. 3-a, seven peaks designated A-G (also referred to as sterols $A-G$ ) were seen. When the stanol fraction prepared by TLC under Condition $C$ was chromatographed, five peaks corresponding to sterols $A-E$ appeared with the similar pattern, and in the case of the Compound $X$ fraction a main peak (peak $F$ ) with a minor peak (peak G) emerged, indicating that Compound $X$ has at least one attendant. The retention time of sterol A agreed with that of standard cholestanol, which had a slightly longer retention time than cholesterol. Sterols B, C and D showed slightly slower retention behavior compared with campesterol, stigmasterol and $\beta$-sitosterol, respectively. A bacterial sample gave a similar result, except that peak $F$ was markedly high relative to other peaks (Fig. 4-a).

On GLC of the oligotrich protozoa incubated for 2 days in the growing system without exogenous steroids, a considerable change in the sterol pattern was shown, compared with the pattern before incubation; the contribution of peak $\mathrm{A}$ to the total picture increased remarkably (Fig. 3-b). It may be certain that this change was not caused by contaminative bacteria, according to the result of the similar experiment carried out with rumen bacteria using the same medium, where no significant change in the relative height of peak A was observed (Fig. 4-b). Since the 
Sterols in Rumen Protozoa

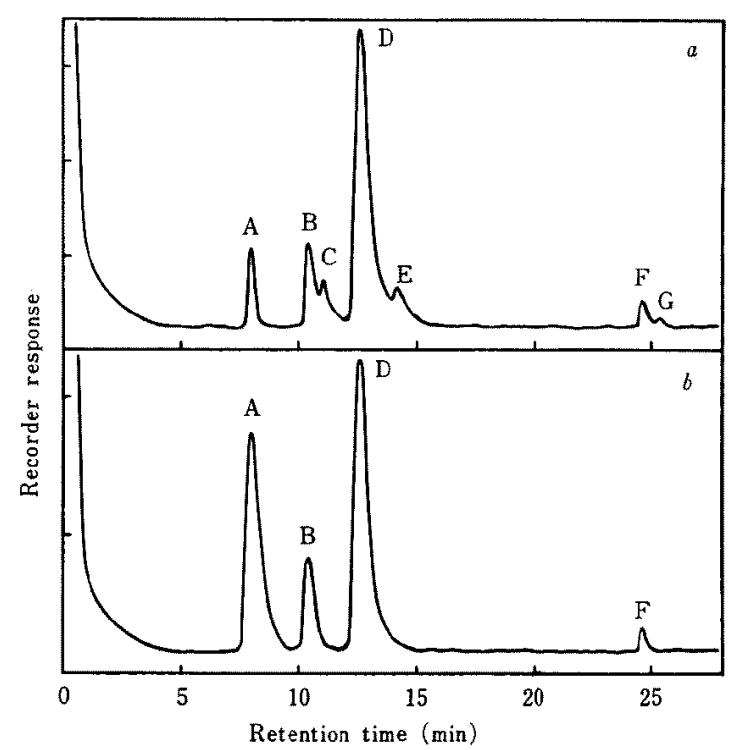

Fig. 3. Gas chromatograms of sterols in rumen oligotrich protozoa.

Combined stanol and Compound $X$ fractions of oligotrich protozoa $(a)$ and those cultured for 2 days without steroids $(b)$ were chromatographed using $1 \mathrm{~m}$ columns packed with $2 \%$ OV-17: Flow rate of carrier gas was $c a .40 \mathrm{~m} l / \mathrm{min}$, injection and detection temperature $290^{\circ} \mathrm{C}$, and column temperature $260^{\circ} \mathrm{C}$.

The sample injected for $b$ was nearly double the quantity for $a$ in terms of wet cell volume.

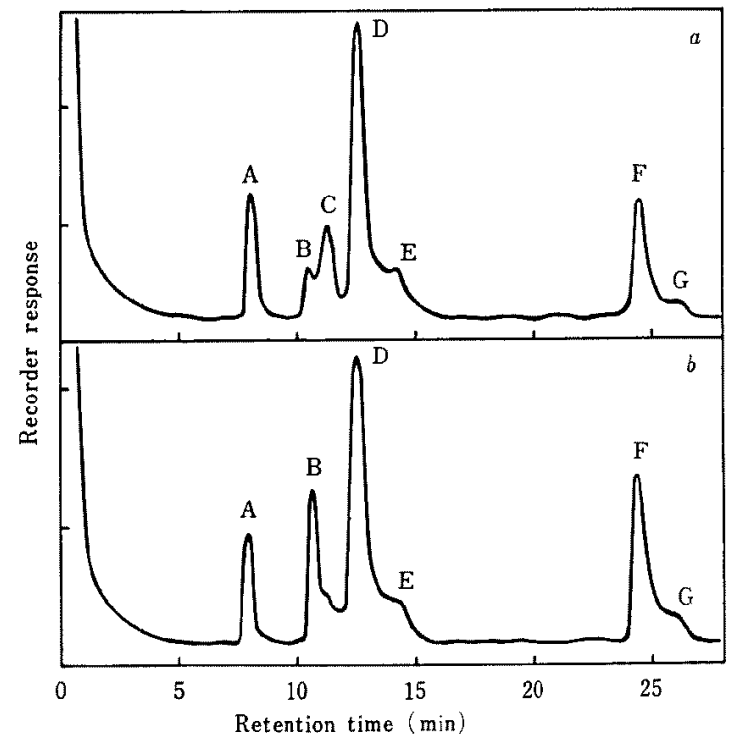

Fig. 4. Gas chromatograms of sterols in rumen bacteria.

Combined stanol and Compound X fractions of bacteria $(a)$ and those cultured for 2 days without steroids $(b)$ were chromatographed under the same conditions as in Fig. 3.

The sample injected for $b$ was nearly double the quantity for $a$ in terms of wet cell volume. 


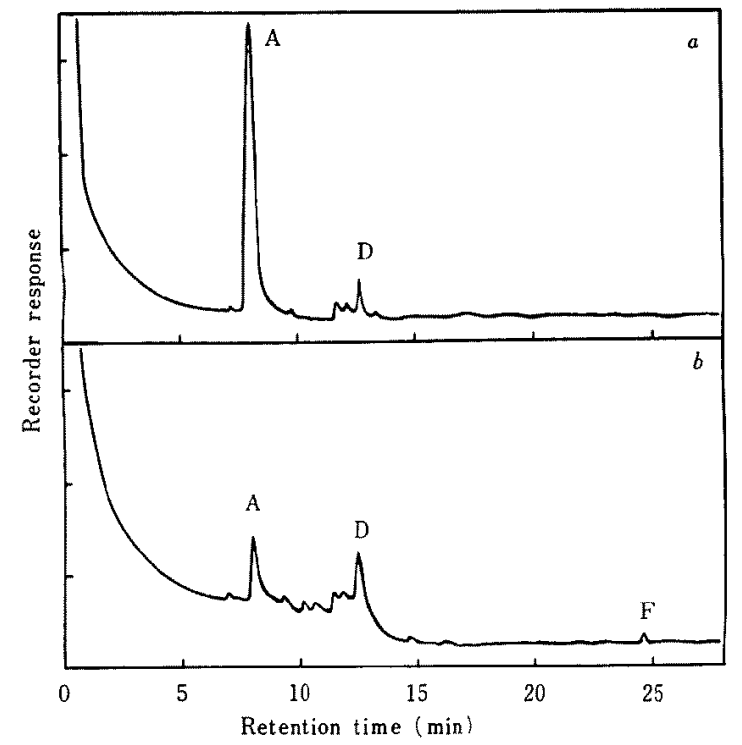

Fig. 5. Gas chromatograms of sterols in rumen oligotrich protozoa and bacteria collected from a goat fed an almost steroid-free ration.

Combined stanol and Compound X fractions of protozoa $(a)$ and bacteria $(b)$ were chromatographed under the same conditions as in Fig. 3. The bacterial sample injected was approx. 5 times the quantity of the protozoal sample in terms of wet cell volume.

medium completely devoid of steroids was used and the protozoa increased nearly double in their number, a possible explanation for the increase in the relative quantity of sterol A may be that this sterol was derived from other sterols such as sterols B-D by metabolic conversion and/or synthesized by protozoa themselves with slower or no synthesis of other sterols. Relative decrease of sterol $\mathrm{C}$ was recorded for both protozoa and bacteria, perhaps indicating that this sterol has a feed origin and undergoes metabolic conversion by protozoa and bacteria.

The total sterol contents in protozoa and bacteria relative to the wet cell volume were markedly reduced by incubation in the absence of steroids (Figs. 3,4), suggesting that sterols were diluted due to cell multiplication. Quantitative aspect of this line is to be discussed below.

The oligotrich protozoa collected from a goat fed an almost steroid-free ration (Diet $\left.D^{21}\right)$ contained an extremely high proportion of sterol A (Fig. 5-a), while in the case of bacteria the pro. portion of sterol A was not so great (Fig. 5-b), the total sterol content in the bacteria being much lower than that in the protozoa. From these results a possibility may be postulated that sterol A is synthesized or derived by protozoa, and then taken up by bacteria from either dead protozoal cells or rumen fluid into which this sterol is excreted by protozoa.

For identification of the major sterols in oligotrich protozoa, GLC analysis was repeated using $2 \mathrm{~m}$ columns, with the result that more clear separation was achieved under this condition. The retention behavior confirmed that sterol $\mathrm{A}$ is identical to cholestanol (Fig. 6). A quite small peak (H) corresponding to coprostanol was also seen. When the $5 \alpha$-stanol fraction collected after TLC separation under Condition $E$ was chromatographed, peaks A-E appeared, while the $5 \beta$-stanol fraction gave peaks H. I and J. Inferring from peak positions, sterols B, D, I and J may be cam- 


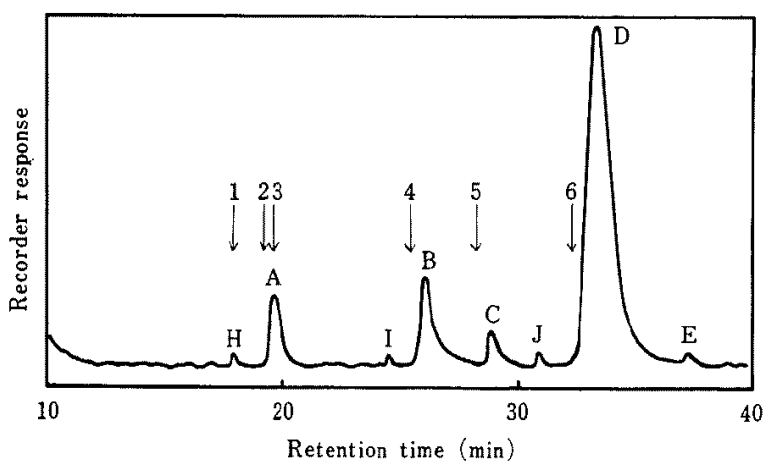

Fig. 6. Gas chromatogram of stanols in rumen oligotrich protozoa.

Stanol fraction was subjected to GLC; $2 \mathrm{~m}$ OV-17 columns were used, flow rate of carrier gas ca. $50 \mathrm{ml} / \mathrm{min}$, injection and detection temperature $290^{\circ} \mathrm{C}$, and column temperature $270^{\circ} \mathrm{C}$.

Arrows indicate the positions of reference sterols; 1) coprostanol, 2) cholesterol, 3) cholestanol, 4) campesterol, 5) stigmasterol, and 6) $\beta$-sitosterol.

pestanol, stigmastanol, coprocampestanol and coprostigmastanol, respectively. A possibility may be postulated that sterol $C$ is 24 -ethyl- $5 \alpha$-cholest- $\int^{22}$-en- $3 \beta-o l$, but this has not been identified yet.

On GLC of the sterol fraction of the feed given to goats during these experiments, peaks corresponding to campesterol, stigmasterol and $\beta$-sitosterol were recorded as the major components, together with much lower peaks that have not been identified, but sterols A-J were not detected.

It may be assumed that stigmastanol and campestanol present in protozoa are derived from these feed sterols, i.e., stigmastanol is derived from $\beta$-sitosterol and stigmasterol, and campestanol from campesterol. The ratio of stigmastanol to campestanol was in good agreement with that of $\beta$-sitosterol plus stigmasterol to campesterol. Possible origins of cholestanol are considered below.

In entodinia the sterols almost similar to those found in oligotrichs were present, with the pattern reflecting the medium sterols, i.e., white clover sterols ${ }^{19}$.

The tomatine-precipitated fraction of oligotrich protozoa and the TMS derivatives of protozoal sterols were also examined, with essentially the same results as those mentioned above.

(3) Analysis by MS

For further identification of the main sterols, GLC-MS was conducted with the oligotrich sample. The mass spectrum of sterol A was identical to that of an authentic cholestanol, where diagnostic ion peaks were; m/e, $388\left(\mathrm{M}^{+}\right), 373\left(\mathrm{M}^{+}-\mathrm{CH}_{3}\right), 370\left(\mathrm{M}^{+}-\mathrm{H}_{2} \mathrm{O}\right), 355\left(\mathrm{M}^{+}-\mathrm{CH}_{3}-\mathrm{H}_{2} \mathrm{O}\right), 275\left(\mathrm{M}^{+-}\right.$ side chain), $257\left(275-\mathrm{H}_{2} \mathrm{O}\right), 233$ (D-ring fission), $215\left(233-\mathrm{H}_{2} \mathrm{O}\right), 165$ (C-ring fission), $147\left(165-\mathrm{H}_{2} \mathrm{O}\right.$ ) and 121 (B-ring fission- $\left.\mathrm{H}_{2} \mathrm{O}\right)$. In the case of sterol $\mathrm{B}$, characteristic peaks, $m / e 402\left(\mathrm{M}^{+}\right), 387\left(\mathrm{M}^{+}-\right.$ $\left.\mathrm{CH}_{3}\right), 384\left(\mathrm{M}^{+}-\mathrm{H}_{2} \mathrm{O}\right)$ and $369\left(\mathrm{M}^{+}-\mathrm{CH}_{3}-\mathrm{H}_{2} \mathrm{O}\right)$ appeared, and peaks $275,233,215,165,147$ and 121 were recorded just as seen on cholestanol. This peak pattern is consistent with the assumption that sterol $\mathrm{B}$ is campestanol. Similarly, sterol $\mathrm{D}$ was demonstrated to be stigmastanol; $\mathrm{m} / \mathrm{e}, 416$ $\left(\mathrm{M}^{+}\right), 401\left(\mathrm{M}^{+}-\mathrm{CH}_{3}\right), 398\left(\mathrm{M}^{+}-\mathrm{H}_{2} \mathrm{O}\right), 383\left(\mathrm{M}^{+}-\mathrm{CH}_{3}-\mathrm{H}_{2} \mathrm{O}\right), 275,233,215,165,147$ and 121.

\section{(4) Quantitative analysis}

Sterol content and composition of oligotrich protozoa determined by GLC are given in Table 1. Total sterol content was usually $0.6-0.9 \%$ on the basis of cell dry weight and $6-7 \%$ on the basis of total lipid weight. In the case of the protozoa incubated in the absence of steroids 
Hino and Kametaka

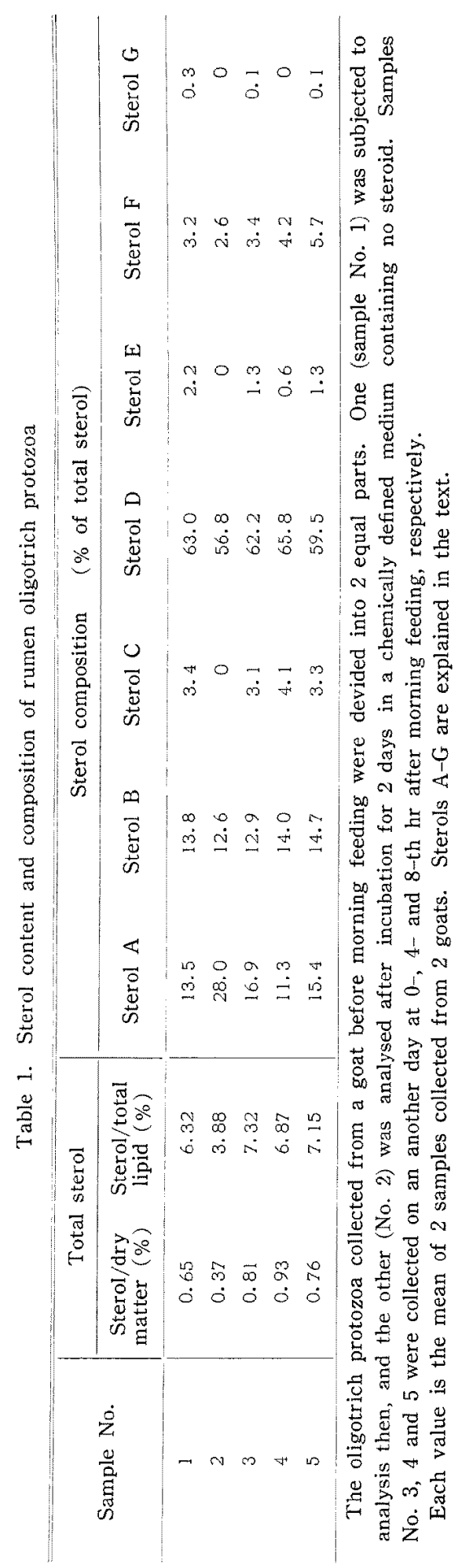

(sample No. 2), sterol content was markedly low. As mentioned above, this may indicate that sterols are diluted due to cell growth with no or, if ever, limited synthesis of sterols: The dry weight of sample No. 2 protozoa was 1.55 -fold that of No. 1 protozoa, i.e., $55 \%$ increase was attained in 2 days, while the absolute amount of total sterols was decreased ( $c a .12 \%$ ) after incubation. In terms of absolute quantity, the value of sterol A for sample No. 2 was markedly higher than that for sample No. I ( $c a .1 .7$-fold). On the contrary, the quantities of other sterols were obviously lower for sample No. 2 than that for sample No.1. Change in the sterol content relative to time after feeding was not significant, but the protozoa collected at 6 th hour (sample No. 4) tended to show slightly higher sterol content, although the value of total sterol per total lipid was somewhat lower due to higher lipid content. No great variation in the sterol composition with time after feeding was observed, but protozoal sterols may probably vary with feed sterols ingested by the host animal.

\section{Discussion}

As the major steroids of rumen oligotrich protozoa, stigmastanol, campestanol and cholestanol were identified. The former two stanols seem to be derived from plant sterols in the rations, such as $\beta$-sitosterol, stigmasterol and campesterol, although the metabolic origin of cholestanol is uncertain. A fairly large amount of 5,3 -stanols was found in the feces of a goat, but the rumen contents contained only a trace of them. This may indicate that the sterol metabolism in the rumen is considerably different from that in the intestine. In man, chicken and rodents 5,3-stanols contribute nearly 50\% of the total fecal sterols ${ }^{24-26)}$, and these stanols have been shown to be formed by intestinal bacterial flora ${ }^{21.27 .28)}$. The significance of the microbial transformation of sterols in animal physiology is not fully known, but it is highly possible that such modification has some influence upon host animals: Dietary plant sterols prevent the in- 


\section{Sterols in Rumen Protozoa}

crease in blood and tissue cholesterol caused by ingestion of cholesterol, as first reported by PETERSON ${ }^{29)}$ for chicks and confirmed since then for many other species. It has been demonstrated that soy sterols increase the cholesterol synthesis in rat liver, and also prevent the depression of cholesterogenesis caused by dietary cholesterol ${ }^{30}$. Furthemore, the effect of phytosterols on total lipid metabolism in the liver of cholesterol-fed rats has been suggested ${ }^{31)}$. Similar effect has been shown for coprostanol, e.g., the stanol exerts a protective effect against tissue cholesterol accumulation in rats fed exogenous cholesterol ${ }^{32}$, and moreover, coprostanol is virtually unabsorbable in intestines ${ }^{33}$. From this viewpoint, the problem as to what implication lies in the conversion to $5 \alpha$-stanols in the rumen appears to be worth investigaring.

On the other hand, with respect to the function of $5 \alpha$-stanols in protozoal cells, there is a possibility that the stanols play a role as a membrane constituent, just as well known for cholesterol and other sterols in various biological membranes. It has been reported that in Saccharomyces cerevisiae ${ }^{34)}$ and Mycoplasma arthritidi ${ }^{35)}$ the requirement for exogenous sterols as a membrane constituent is satisfied with $5 \alpha$-stanols, but not with $5 \beta$-stanols. In Tetrahymena a sterollike compound, tetrahymanol, is believed to be important for the membrane architecture, and tetrahymanol can be replaced with sterols, if supplemented to the medium ${ }^{36}$.

As the role of sterols in rumen protozoa, however, another possibility, i. $e_{n}$, more direct effect on the metabolic function, should not be denied at present.

Remarkable increase in the absolute quantity of cholestanol was found after incubation of oligotrich protozoa without exogenous steroids. This indicates that cholestanol is either synthesized de novo or derived from other sterols by the protozoa. That other sterols such as stigmastanol and campestanol were decreased in their absolute quantities may be explained as follows; (1) these sterols underwent metabolic conversion, (2) the sterols initially present in the protozoa were expelled out of the cells, or (3) the protozoa containing these sterols initially were partially disrupted. The increase of cholestanol did not compensate for the decrease of other sterols, and as the result, the absolute amount of total sterols was decreased and the sterol content per protozoal dry weight was still more greatly lowered down due to cell growth. This may explain the fact that the protozoa require exogenous sterols. The gradual decrease of growth rate without exogenous sterols may, at least in part, be due to the decrease of sterol content.

Further identification of the minor sterols, such as Compound $\mathrm{X}$, is in progress. Furthermore, an investigation to find other trace steroids should be desirable, because there is a possibility that trace steroids exert significant effects on biological activities, like steroid hormones in higher animals, insects and so on.

We wish to express our thanks to Dr. K. Aizawa of this department for the operation of mass spectrometer.

\section{References}

1) Hino, T., M. Kametaka, and M. Kandatsu, J Gen Appl Microbiol 19: 397-413. 1973.

2) Hino, T., and M. Kametaka, Jap J Zootech Sci 45: 223-232. 1974.

3) Conner, R. L., W. J. van Wagtendonk, and C. A. Miller, J Gen Microbiol 9: 434-439. 1953.

4) van Wagtendonk, W. J., R. L. Conner, C. A. Miller, and M. R. R. Rao, Ann NY Acad Sci 56: 929-937. 1953.

5) Conner, R. L. and W. J. van Wagtendonk, J Gen Microbiol 12:31-36. 1955.

6) HoLz, G. G., Jr., J Protozool 4: Suppl. 11-12. 1957.

7) HoLz, G. G., Jr., and J. ERwin, J Protozool 5: Suppl. 19. 1958. 
8) Holz, G. G., Jr., B. Wagner, J. Erwin, J. J. Britt, and K. Bloch, Comp Biochem Physiol 2: 202-217. 1961.

9) Stillwell, R. H., and D. M. Lilly, Am Zoologist 2: 562-563. 1962.

10) Lilly, D. M., and R. H. Stillwell, Science 147: 747-748. 1965.

11) Lilly, D. M., and W.H. Cervallos, Trans N Y Acad Sci 18: 531-540. 1956.

12) Clark, A. J., and K. Bloch, J Biol Chem 234: 2583-2588. 1959.

13) Buetow, D. E, and B. H. Levedahl, Ann Rev Microbiol 18: 167-194. 1964.

14) Rodwell, A. W., J.E. Peterson, and E. S. Rodwell, Pathogenic Mycoplasma, 123-144. A Ciba Foundation Symposium, Associated Scientific Publishers. Amsterdam. 1972.

15) Hendrix, J. W., Ann Rev Phytopathol 8: 111-130. 1970.

16) Katz, I.-and M. Keeney, Biochim Biophys Acta 144: 102-112. 1967.

17) Hino, T., M. Kametaka, and M. Kandatsu, J Gen Appl Microbiol 19: 325-337. 1973.

18) Aвou Akkada, A. R., and B. H. Howard, Biochem J 76: 445-451. 1960.

19) Hino, T., and M. KametakA, J Japan Grassl Sci 19: 379-388, 1973.

20) Copius-Peereboom, J.W., and H.W. Beekes, J Chromatog 17: 99-113. 1965.

21) Martin, W. J., M.T.R. Subbiah, B. A. Kottke, C.C. Birk, and M.C. Naylor, Lipids 8: 208215. 1973.

22) Hino, T., M. Kametaka, and M. Kandatsu, J Gen Appl Microbiol 19: 305-315. 1973.

23) Avigan, J., D. S. Goodman, and D. Stennberg, J Lipid Res 4: 100-108. 1963.

24) Wells, W. W., and M. Makita, Anal Biochem 4: 204-212. 1962.

25) Eneroth, P., K. Hellström and R. Ryhage, J Lipid Res 5: 245-251. 1964.

26) Subbiah, M. T.R., B. A. Kortke, and P.E. Zollman, Comp Biochem Physiol 41: 695-704. 1972.

27) Rosenfeld, R. S., D. K. Fukushima, H. L. Hellman, and T. F. Gallagher, J Biol Chem 211 : 301-311. 1954.

28) Rosenfeld, R. S., and T.F. Gallagher, Steroids 4: 515-520. 1964.

29) Peterson, D.W., Proc Soc Exp Biol Med 78: 143-148. 1951.

30) Fishler-Mates, Z., P. Budowski, and A. Pinsky, Lipids 8: 40-42. 1973.

31) Kiribuchi, T., K. Somda, T. Baba, Y. Nozawa, and C. Inagaki, J Jap Soc Food and Nutr 26: 491-495. 1973 .

32) Kellogg, T.F., Fed Proc Fed Amer Soc Exp Biol 30: 1808-1810. 1971.

33) Iritani, N., and W.W. Wells, J Lipid Res 7: 372-376. 1966.

34) Proudlock, J.W. Wheeldon, D. J. Jollow, and A. W. Linnane, Biochim Biophys Acta 152: 434-437, 1968.

35) Smith, P. L., The Biology of Mycoplasmas 1-94. Academic Press Inc. New York. 1971.

36) Ferguson, K, A., R. L. Conner, and F. B. Mallory, Arch Biochem Biophys 144: 448-450. 1971. 


\title{
貧毛目 (Oligotrich) の反すう胃内原虫中のステロール
}

\author{
日野常男・亀 高正 夫
}

東京大学農学部, 東京都 113

督毛目の反寸う胃内原虫の生育がステロール類により 促進されることの理由を説明するための第一段階とし て，搷取されたステロールが虫体内でどのような形で利 用されるが明らかにするととを目的として，貿毛目原 虫中のステロイドを分析した，原虫の主要ステロイドと Lて (a)24-ethyl-5 $\alpha$-cholestan-3 $\beta$-ol, (b) 24-methyl-5 $\alpha$ -

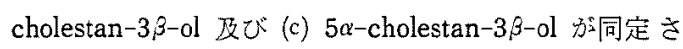
れ，また少量ながら上記スタノールの5 3 -異性体及びそ の他の未同定ステロール類が存在することが示された.

(a)及び(b)は飼料中のステロールの水素添加に上り生成さ れたものと推測されたが，(c)の成因汸明らかでない。

原虫中の総ステロール含量は乾物当り $0.6 \sim 0.9 \%$ ，総脂 質当り6〜7\%であり，ステロールの組成は(a)60６6\%， (b)13〜15\%，(c)11〜17\%及びその他7〜9\%であった. ス

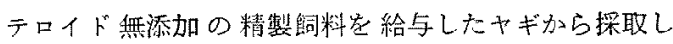
た原虫では(c)の割合が著しく高かった。ステロイドを全 く含まない培地で短期間培鉒した原虫です(c)の割合が顥 著に高く，またとの絶対量も增加したが，乾物当りの総

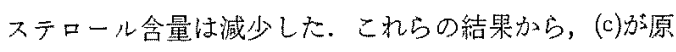
虫により合成されるふ，又は他のステロールから誘導さ れる可能性が考光られる。しタし，総ステロール含量が 隇少したここは，たとえ(c)か源虫により合成されるとし ても，細胞の增殖速度に比べてその合成速度が極めて掘 いことを示主之考えられ，このことから，原虫は膜成分 としてのステロールを外因性のもので補充しているとい う可能性が推察される. 